\title{
CATHODOLUMINESCENCE STUDIES OF THE 1.4 eV BANDS IN CdTe (*)
}

\author{
C. B. NORRIS and C. E. BARNES
}

Sandia Laboratories, Albuquerque, New Mexico 87115, U. S. A.

\begin{abstract}
Résumé. - On a effectué des mesures de luminescence dans la bande voisine de 1,4 eV par cathodoluminescence à $80 \mathrm{~K}$, sur divers types de cristaux de tellurure de cadmium : purs, stœchiométriques, compensés par un donneur sous excès de tellure. Ce travail constitue la première approche tenant compte à la fois de l'influence du niveau d'injection, de la réponse transitoire et de la coupure sous l'effet de la température. Nous avons établi que cette bande de luminescence possède les caractéristiques suivantes : la forme de la bande et la position du pic sont indépendants du niveau d'injection tant que les bandes ne se chevauchent pas ; la transition est lente avec des constantes de temps de l'ordre de 1 à $5 \mu$ s; ce temps de transition est indépendant du niveau de dopage lorsque celui-ci varie de trois ordres de grandeur ; l'intensité de la luminescence croît avec la concentration en donneurs ; la luminescence présente un phénomène de coupure avec la température avec une énergie d'activation relativement importante. L'ensemble de ces résultats ne peut-être expliqué à l'aide des mécanismes de transitions classiques, qui sont bien établis. Comme chacun de ces résultats est en accord avec certaines données de la littérature, nous devons supposer que cette transition est plus complexe que ce qui était supposé jusqu'ici, plutôt que de considérer l'existence de plusieurs transitions dans les divers matériaux.
\end{abstract}

\begin{abstract}
Using cathodoluminescence at $80 \mathrm{~K}$, we have studied the $1.4 \mathrm{eV}$ luminescence bands in nominally undoped, nominally stoichiometric CdTe and in donor-compensated, Te-rich CdTe. The present work represents the first combined measurements of injection level dependence, transition response and thermal quenching for these materials. We find that the $1.4 \mathrm{eV}$ luminescence has the following characteristics : 1) the band shape and peak position are independent of injection level, except for those samples having overlapping bands, 2) the transition is slow, with characteristic times on the order of $1-5 \mathrm{E}-6 \mathrm{~s}, 3$ ) the transition response time is approximately constant over three orders of magnitude in doping level, 4) the luminescence intensity increases with donor doping level, and 5) the luminescence shows thermal quenching with a relatively large activation energy. This combination of characteristics is not explicable in terms of well-understood transition mechanisms. While the results of our individual measurements are similar to results from corresponding measurements in the literature, it is clear from the present work that the contradictory conclusions of previous investigators regarding the nature of the $1.4 \mathrm{eV}$ transitions in CdTe arose from the fact that this transition is of a more complex nature than generally appreciated rather than from the appearance of different types of transitions in different CdTe samples.
\end{abstract}

1. Introduction. - Observations of broad emission bands centered near $1.4-1.45 \mathrm{eV}$ were noted in the earliest investigations of luminescence in $\mathrm{CdTe}$ [1-3]. These bands, which can be seen in CdTe samples prepared in practically every laboratory [1-24], have appeared so persistently that they have sometimes been discussed [3] in conjunction with the edge emission of CdTe, which occurs between 1.5 and $1.6 \mathrm{eV}$. After two decades of research on $\mathrm{CdTe}$, which has seen great improvements in material quality, the $1.4 \mathrm{eV}$ bands still appear in all but the purest specimens. The origin of these bands is the subject of the present paper.

Certain basic aspects of the $1.4 \mathrm{eV}$ bands in CdTe are understood. From the published investigations of many workers [4-16] it can be concluded that the bands

(*) This work was supported by the United States Energy Research and Development Administration under Contract E(29-1)789. are enhanced by addition of impurities and by deviation either way from nominal $1: 1$ stoichiometry. Therefore, it is generally accepted that the $1.4 \mathrm{eV}$ bands involve both impurities and native defects of some sort. It is also believed that the transitions responsible for these bands terminate on moderately deep acceptor levels that are the order of $0.1 \mathrm{eV}$ from the valence band [4-22]. Lastly, generally similar bands in the range 1.4 to $1.45 \mathrm{eV}$ have been observed in CdTe whether the material is Cd-rich, Te-rich, or nominally stoichiometric. The results of a literature survey on the $1.4 \mathrm{eV}$ bands in CdTe are summarized in table $\mathrm{I}$.

Despite the prominence of the $1.4 \mathrm{eV}$ bands and their long history of observation, the possible origins of these bands remain a subject of much controversy. As shown in table I, there are a variety of apparent contradictions between results and conclusions of various groups who have studied the $1.4 \mathrm{eV}$ bands. One problem is that the bands may have different 


\section{TABLE I}

Summary of prior work on the $1.4 \mathrm{eV}$ bands in $\mathrm{CdTe}$. The results are grouped according to whether the majority of samples studied were $\mathrm{Cd}-$ Rich (CdTe), Te-Rich (CdTe) or nominally stoichiometric or unspecified (CdTe). Assignments into these categories, as well as interpretations and conclusions, are sometimes our own. Abreviations and symbols used : «il»= injection level ; «T»= temperature ; $D \rrbracket=$ donor ;

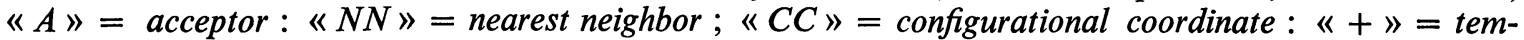
perature of $20 \mathrm{~K}$; «o»= phonon structure not resolved.

\begin{tabular}{|c|c|c|c|c|c|c|c|c|}
\hline $\begin{array}{l}\text { [Ref.] } \\
\text { Author } \\
\text { (Date) }\end{array}$ & & 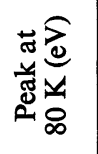 & 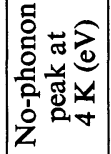 & 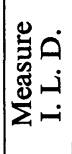 & 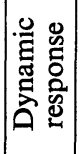 & 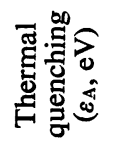 & Remarks & $\begin{array}{l}\text { Conclusion as to } \\
\text { nature of } 1.4 \mathrm{eV} \text { band }\end{array}$ \\
\hline $\begin{array}{c}\text { [8-13] } \\
\text { Taguchi, } \\
\text { et al. } \\
(1972-1975)\end{array}$ & $\begin{array}{l}\text { CdTe } \\
\text { CdTe : Cl } \\
\text { CdTe : Ga }\end{array}$ & 1.42 & $\begin{array}{l}1.451- \\
1.455 \\
1.40_{0} \\
1.377_{0}\end{array}$ & $x$ & $x$ & $\begin{array}{l}0.16 \\
0.16\end{array}$ & $\begin{array}{l}1.4 \mathrm{eV} \text { band enhanced by } \mathrm{Cd} \\
\text { excess; suppressed by } \mathrm{Cd} \\
\text { loss. Band very strong when } \\
\text { both Cl donors and excess } \mathrm{Cd} \\
\text { are present. Time-resolved } \\
\text { spectra shift to lower energies } \\
\text { at longer times, but samples } \\
\text { used have overlapping bands. } \\
\mathrm{Cd} \text { firing at } 900^{\circ} \mathrm{C} \text { lowers } \\
\text { peak energy of } 1.4 \mathrm{eV} \text { band. } \\
\text { In sample fired in low PCd } \\
\text { and quenched, band is very } \\
\text { weak; band is now enhanced } \\
\text { by } \mathrm{e}^{-} \text {or } \mathrm{n} \text { irradiation and } \\
100^{\circ} \mathrm{C} \text { anneal. }\end{array}$ & $\begin{array}{l}\text { Transitions between spatially } \\
\text { separated donors }\left(\varepsilon_{\mathrm{c}}-0.02 \mathrm{eV}\right) \\
\text { and acceptors }\left(\varepsilon_{\mathrm{v}}+0.16 \mathrm{eV}\right) \\
\text { Donors are possibly Cd } \\
\text { acceptors are complexes in- } \\
\text { volving } V_{\mathrm{Te}} \text {. Mean D-A } \\
\text { separation must be } 100-200 \AA \\
\text { to explain slow time decay } \\
\text { this seems inconsistent with } \\
\text { stability of } 1.4 \mathrm{eV} \text { band under } \\
\text { Cd-firings or n-irradiations } \\
\text { that severely quench edge } \\
\text { emission. Il shift is used as } \\
\text { evidence for D-A pair nature } \\
\text { of band but shift is only } \\
4.5 \text { meV for } 800 \times \text { increase } \\
\text { in il. }\end{array}$ \\
\hline $\begin{array}{l}\text { [4] } \\
\text { Vavilov, } \\
\text { et al. } \\
\text { (1967) }\end{array}$ & $\begin{array}{l}\text { CdTe } \\
\overline{\text { CdTe }: \text { In }} \\
\overline{\text { CdTe }: A l} \\
\overline{\text { CdTe }}\end{array}$ & $\begin{array}{l}1.43 \\
1.42 \\
1.42\end{array}$ & $\begin{array}{l}1.45^{+} \\
1.47^{+}\end{array}$ & & & & $\begin{array}{l}\text { Intensity of } 1.4 \mathrm{eV} \text { band increa- } \\
\text { ses with In or Al or excess Cd } \\
\text { content, decreases with vac } \\
\text { annealing. }\end{array}$ & $\begin{array}{l}\text { Transitions between spatially } \\
\text { separated shallow donors and } \\
\text { deep acceptors. }\end{array}$ \\
\hline $\begin{array}{l}\text { [14] } \\
\text { Rud' } \\
\text { et al. } \\
\text { (1971) }\end{array}$ & $\begin{array}{l}\mathrm{CdTe}: \mathrm{A} \\
\overline{\mathrm{Cd} T e} \\
\overline{\mathrm{CdTe}}\end{array}$ & $\begin{array}{l}1.41 \\
\text { No } \\
\text { No }\end{array}$ & $\begin{array}{l}\text { Band } \\
\text { Band }\end{array}$ & & & & $\begin{array}{l}1.4 \mathrm{eV} \text { band increases with } \\
\text { excess Cd and with unknown } \\
\text { acceptor conc. Band quen- } \\
\text { ched by firing in vac or Te } \\
\text { vapor. Slow cooling rate } \\
\text { enhances band ; quenching } \\
\text { destroys it. }\end{array}$ & $\begin{array}{l}\text { Intracenter transitions in D-A } \\
\text { complex of Cd } d_{i} \text {-impurity ty- } \\
\text { pe. Donor level is shallow } \\
\text { and acceptor level is deep } \\
\left(\varepsilon_{\mathrm{v}}+0.15 \mathrm{eV}\right) \text {. Centers ap- } \\
\text { pear unaffected by change } \\
\text { from p-to n-type CdTe. }\end{array}$ \\
\hline $\begin{array}{l}{[18]} \\
\text { Panossian, } \\
\text { et al. } \\
(1969)\end{array}$ & $\mathrm{CdTe}$ & 1.42 & $1.453^{+}$ & & & & $\begin{array}{l}\text { Phonons interact strongly with } \\
\text { acceptor and weakly with } \\
\text { donor. }\end{array}$ & $\begin{array}{l}\text { Transitions between spatially } \\
\text { separate donors } \\
\left(\varepsilon_{\mathrm{c}}-0.015 \mathrm{eV}\right) \\
\text { and acceptors }\left(\varepsilon_{\mathrm{v}}+0.14 \mathrm{eV}\right)\end{array}$ \\
\hline $\begin{array}{l}\text { [23] } \\
\text { Noblanc and } \\
\text { Duraffourg } \\
(1971)\end{array}$ & $\mathrm{CdTe}$ & & 1.451 & & & & $\begin{array}{l}\text { Some samples show sharp lines } \\
\text { on the broader phonon repli- } \\
\text { cas of the } 1.451 \mathrm{eV} \text { band at } \\
4 \mathrm{~K} \text {. Lines result from recom- } \\
\text { bination at oxygen isoelectro- } \\
\text { nic trap. }\end{array}$ & $\begin{array}{l}\text { There is no apparent explana- } \\
\text { tion for } 1.4 \mathrm{eV} \text { band in terms } \\
\text { of recombination at oxygen } \\
\text { iso-electronic traps. }\end{array}$ \\
\hline $\begin{array}{c}{[22]} \\
\text { Barnes and } \\
\text { Kikuchi } \\
(1975)\end{array}$ & $\mathrm{CdTe}$ & & 1.45 & & & & $\begin{array}{l}\text { Selective displacement of } \mathrm{Cd} \\
\text { by thermal neutron irradia- } \\
\text { tion enhances } 1.4 \mathrm{eV} \text { band in } \\
\text { some samples, and decreases } \\
\text { band in other samples, relati- } \\
\text { ve to edge emission. }\end{array}$ & $\begin{array}{l}\text { Transitions to acceptor level } \\
\text { arising from complex com- } \\
\text { posed of Cd defect and donor } \\
\text { impurity. }\end{array}$ \\
\hline $\begin{array}{l}\text { Present } \\
\text { Work }\end{array}$ & $\mathrm{CdTe}$ & 1.44 & $1.44_{0}$ & $x$ & $x$ & 0.103 & $\begin{array}{l}\text { Samples are nominally stoi- } \\
\text { chiometric and undoped but } \\
\text { show overlapping bands. }\end{array}$ & $\begin{array}{l}\text { As described for our work on } \\
\text { Te-rich CdTe. }\end{array}$ \\
\hline $\begin{array}{c}{[15]} \\
\text { Bryant and } \\
\text { Totterdell } \\
(1972)\end{array}$ & $\begin{array}{l}\text { CdTe } \\
\text { CdTe }\end{array}$ & 1.42 & \begin{tabular}{|c|}
1.451 \\
$(8 \mathrm{~K})$ \\
1.451 \\
$(8 \mathrm{~K})$
\end{tabular} & & & 0.13 & $\begin{array}{l}1.4 \mathrm{eV} \mathrm{band} \mathrm{enhanced} \mathrm{by} \\
300 \mathrm{~K} \mathrm{e} \mathrm{e}^{-} \text {irradiation capable } \\
\text { of displacing Cd only. Band } \\
\text { is enhanced by vacuum firing } \\
\text { but unaffected by firing for } \\
\text { unspecified time at low } P_{\mathrm{Cd}} \text {. }\end{array}$ & $\begin{array}{l}\text { Transitions to acceptor levels } \\
\text { at approx. } \varepsilon_{\mathrm{v}}+0.15 \mathrm{eV} \\
\text { resulting from complex cen- } \\
\text { ter containing } V_{\mathrm{Cd}} \text { and possi- } \\
\text { bly impurity atoms. Comple- } \\
\text { xes are insensitive to firing } \\
\text { treatments that affect edge } \\
\text { emission. Thermal quenching } \\
\text { suggests CB-A transitions. }\end{array}$ \\
\hline
\end{tabular}


TABLE I (Suite)

\begin{tabular}{|c|c|c|c|c|c|c|c|c|}
\hline $\begin{array}{l}\text { [Ref.] } \\
\text { Author } \\
\text { (date) }\end{array}$ & 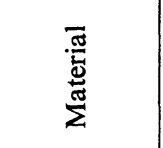 & 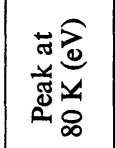 & 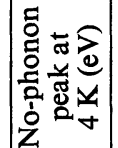 & 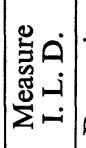 & 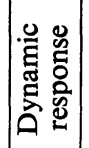 & 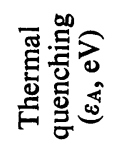 & Remarks & $\begin{array}{c}\text { Conclusion as to } \\
\text { nature of } 1.4 \mathrm{eV} \text { band }\end{array}$ \\
\hline $\begin{array}{l}{[17]} \\
\text { Bryant, } \\
\text { et al. } \\
(1972) \\
\end{array}$ & $\mathrm{CdTe}$ & 1.41 & $\begin{array}{c}1.42_{0} \\
(8 \mathrm{~K})\end{array}$ & & & 0.106 & $\begin{array}{l}\text { Thermal quenching data sug- } \\
\text { gests CB-A transition. Peak } \\
\text { shifts with } T ; 4 \mathrm{~K} \text { phonon } \\
\text { structure not well resolved. } \\
\end{array}$ & $\begin{array}{l}\text { CB-A transitions. Acceptor } \\
\text { level produced by complex } \\
\text { involving Cd defect. }\end{array}$ \\
\hline $\begin{array}{c}{[16]} \\
\text { Bryant and } \\
\text { Webster } \\
(1968)\end{array}$ & $\begin{array}{l}\text { CdTe } \\
\text { CdTe }\end{array}$ & $\begin{array}{l}1.40 \\
1.40\end{array}$ & & & & 0.24 & $\begin{array}{l}\text { Firing in Cd vapor at moderate } \\
\text { time and } P_{\text {Cd suppresses } 1.4} \\
\text { eV band. Further firing cau- } \\
\text { ses similar band to appear; } \\
\text { this band increases with firing } \\
\text { time and } P_{\text {Cd. }} \text {. Firing changes } \\
\text { CdTe to } \underline{\text { CdTe. }}\end{array}$ & $\begin{array}{l}\text { CB-A transitions. Acceptor } \\
\text { levels are associated with a } \\
\text { complex involving } V_{\text {Cd. Ac- A }} \\
\text { ceptor level assigned at at } \\
\varepsilon_{\mathrm{v}}+0.16 \mathrm{eV} \text {, despite thermal } \\
\text { quenching activation energy } \\
\text { of } 0.24 \mathrm{eV} \text {. }\end{array}$ \\
\hline $\begin{array}{l}{[24]} \\
\text { Bryant } \\
\text { et al. } \\
(1968)\end{array}$ & CdTe & 1.44 & 1.457 & & & & $\begin{array}{l}\text { Electron irradiations at } 15 \mathrm{~K} \\
\text { producing isolated } V_{\mathrm{Cd}} \text { or } \\
V_{\mathrm{Cd}} \text { and } V_{\mathrm{Te}} \text { suppress } 1.4 \mathrm{eV} \\
\text { band while inducing higher- } \\
\text { energy bands. }\end{array}$ & $\begin{array}{l}1.4 \mathrm{eV} \text { band involves complex } \\
\text { defects rather than isolated } \\
V_{\mathrm{Cd}} \text { or } V_{\mathrm{Te}} .\end{array}$ \\
\hline $\begin{array}{c}{[6]} \\
\text { Agrinskaya, } \\
\text { etal. } \\
(1970)\end{array}$ & $\begin{array}{l}\mathrm{CdTe}: \text { In } \\
\text { CdTe }: \mathrm{Cl}\end{array}$ & 1.42 & $\begin{array}{l}1.45 \\
1.47\end{array}$ & $\begin{array}{l}x \\
\times\end{array}$ & & & $\begin{array}{l}1.4 \mathrm{eV} \text { band grows on firing in } \\
\text { vac or Te vapor. No peak } \\
\text { shift with il or T. Half-width } \\
\text { increases strongly with } T \text {. No } \\
\text { FC shift between lum and } \\
\text { abs. } \Delta \varepsilon \text { between In and Cl } \\
\text { doping suggests NN } V_{C d}-\mathrm{D} \\
\text { complexes. }\end{array}$ & $\begin{array}{l}\text { Transitions from CB to accep- } \\
\text { tor levels at } \varepsilon_{\mathrm{V}}+0.15 \mathrm{eV} \\
\text { resulting from compact or } \\
\mathrm{NN} V_{\mathrm{Cd}}-\mathrm{D} \text { complexes. } \\
\text { Gaussian band shape at } 80 \\
300 \mathrm{~K} \text {, half-width variation, } \\
\text { and absence of peak shift } \\
\text { suggest CC model for } V_{\mathrm{Vd}}-\mathrm{D} \\
\text { complex. However, absence } \\
\text { of } \mathrm{FC} \text { shift not discussed. }\end{array}$ \\
\hline $\begin{array}{c}{[7]} \\
\text { Agrinskaya, } \\
\text { et al. } \\
(1971)\end{array}$ & $\begin{array}{l}\mathrm{CdTe}: \text { In } \\
\mathrm{Cd} \overline{\mathrm{Te}}: \mathrm{Al} \\
\mathrm{CdTe}: \mathrm{Cl} \\
\mathrm{Cd} \overline{\mathrm{Te}}: \text { In }\end{array}$ & 1.42 & $\begin{array}{l}1.44 \\
1.446 \\
1.43_{0} \\
1.42_{0}\end{array}$ & $\begin{array}{l}\times \\
\times \\
\times \\
\times\end{array}$ & & $\begin{array}{l}0.155 \\
0.13\end{array}$ & $\begin{array}{l}\text { Thermal activation energies } \\
\text { nearly agree with acceptor } \\
\text { depth assuming transition } \\
\text { from CB or states close in } \\
\text { energy. Peak shifts only } 2 \\
\text { meV for } 100 \times \text { increase in il } \\
<10 \mathrm{meV} \text { with } T \text { from } 77 \mathrm{~K} \\
\text { to } 300 \mathrm{~K} \text {. PC peak appears } \\
\sim 0.05 \mathrm{eV} \text { above lum peak. } \\
\end{array}$ & $\begin{array}{l}\text { Transitions within compact or } \\
\text { NN } V_{\mathrm{Cd}}-\mathrm{D} \text { complexes. Ac- } \\
\text { ceptor-like ground state at } \\
\text { approx. } \varepsilon_{\mathrm{v}}+0.15 \text { eV. Do- } \\
\text { nor-like excited state near } \varepsilon_{\mathrm{c}} \\
\text { Characteristics of complex } \\
\text { consistent with CC model, } \\
\text { but abs. not measured. }\end{array}$ \\
\hline $\begin{array}{c}{[5]} \\
\text { Agrinskaya, } \\
\text { et al. } \\
(1971)\end{array}$ & $\begin{array}{l}\text { CdTe : In } \\
\text { (Ion } \\
\text { impl.) }\end{array}$ & & 1.457 & & & & $\begin{array}{l}1.4 \mathrm{eV} \text { band appears after In } \\
\text { implantation. Annealing en- } \\
\text { hances band with little chan- } \\
\text { ge in spectrum. }\end{array}$ & $\begin{array}{l}\text { CB-A transitions. Acceptor } \\
\text { level associated with } V_{\mathrm{Cd}}-\mathrm{In} \\
\text { complexes. }\end{array}$ \\
\hline $\begin{array}{l}{[10,12,13]} \\
\text { Taguchi, } \\
\text { et al. } \\
(1973-1975)\end{array}$ & $\begin{array}{l}\mathrm{CdTe} \\
\mathrm{Cd} \overline{\mathrm{Te}} \\
\mathrm{Cd} \overline{\mathrm{Te}}: \mathrm{Cl}\end{array}$ & 1.42 & $\begin{array}{l}.45 \\
1.427 \\
1.43\end{array}$ & & & & $\begin{array}{l}\text { Participation of complex de- } \\
\text { fects in } 1.4 \mathrm{eV} \text { band is sup- } \\
\text { ported by fact that } 77 \mathrm{~K} \text { e } \\
\text { irrad'n suppresses band, } \\
\text { while } 300 \mathrm{~K} \text { irradiation } \\
\text { enhances band. THM growth } \\
\text { suppresses band, possibly be- } \\
\text { cause of higher purity. }\end{array}$ & $\begin{array}{l}\text { Implied that } 1.4 \mathrm{eV} \text { band arises } \\
\text { from randomly-distributed } \\
\text { shallow donors and deep } \\
\text { acceptors. Possible origins of } \\
\text { these levels in CdTe are not } \\
\text { discussed. }\end{array}$ \\
\hline $\begin{array}{c}{[19,20]} \\
\text { Furgolle, } \\
\text { et al. } \\
\text { Marfaing, } \\
\text { et al. } \\
(1974-1975)\end{array}$ & $\begin{array}{l}\mathrm{CdTe}: \text { In } \\
\mathrm{CdT \overline {T }}: \mathrm{Al} \\
\mathrm{Cd} \overline{\mathrm{Te}}: \mathrm{Cl} \\
\mathrm{Cd} \overline{\mathrm{Te}}\end{array}$ & & $\begin{array}{l}1.457 \\
1.451 \\
1.478 \\
1.477\end{array}$ & & & & $\begin{array}{l}\text { Optical abs shows transitions } \\
\text { of holes bound to deep accep- } \\
\text { tors at } \varepsilon_{\mathrm{V}}+0.13 \text { eV. Strong } \\
\text { coupling to vibronic mode } \\
\text { with energy < TA phonon } \\
\text { energy indicates compact } \\
V_{\mathrm{Cd}-\mathrm{D} \text { complex. }}\end{array}$ & $\begin{array}{l}\text { Transitions to acceptor levels, } \\
\text { resulting from } V_{\mathrm{Cd}}-\mathrm{D} \text { com- } \\
\text { plexes, at } \varepsilon_{\mathrm{v}}+0.13 \mathrm{eV} \text {. } \\
\text { Implication that transitions } \\
\text { originate on shallow donor } \\
\text { levels }\left(\varepsilon_{\mathrm{c}}-0.01 \mathrm{eV} \text { that are }\right. \\
\text { spatially separated from ac- } \\
\text { ceptor complexes. }\end{array}$ \\
\hline $\begin{array}{c}{[2]} \\
\text { Fatehally } \\
\text { (as quoted) } \\
\text { (1959) }\end{array}$ & $\mathrm{CdTe}$ & $\sim 1.3$ & & & & & $\begin{array}{l}\text { No Franck-Condon shift bet- } \\
\text { ween emission and excitation } \\
\text { bands. Relatively impure } \\
\text { samples. }\end{array}$ & \begin{tabular}{|l} 
ransitions from $\mathrm{CB}$ to \\
acceptor level, associated \\
with $V_{\mathrm{Cd}}$, at $\varepsilon_{\mathrm{V}}+0.15 \mathrm{eV}$.
\end{tabular} \\
\hline $\begin{array}{l}{[3]} \\
\text { Halsted } \\
\text { et al. } \\
(1961)\end{array}$ & $\begin{array}{l}\mathrm{CdTe} \\
\mathrm{Cd} \overline{\mathrm{Te}}: \mathrm{Ga} \\
\mathrm{CdTe}: \mathrm{Ag}\end{array}$ & & $\left|\begin{array}{l}1.451^{+} \\
1.415_{0}^{+} \\
1.49^{+}\end{array}\right|$ & & & & $\begin{array}{c}\text { Spectra depend on identity of } \\
\text { impurity on defect. } 1.4 \mathrm{eV} \\
\text { bands in these samples sup- } \\
\text { pressed with increased } P_{\mathrm{Cd} .}\end{array}$ & $\begin{array}{l}\text { Transition terminating on ac- } \\
\text { ceptor levels attributed to } \\
V_{\mathrm{Cd}} \text { or impurities. }\end{array}$ \\
\hline
\end{tabular}


TABLE I (Suite)

\begin{tabular}{|c|c|c|c|c|c|c|c|c|}
\hline $\begin{array}{l}\text { [Ref.] } \\
\text { Author } \\
\text { (Date) }\end{array}$ & 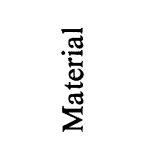 & 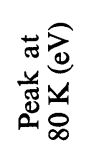 & 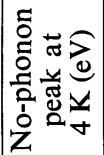 & 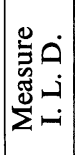 & 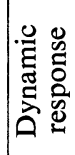 & 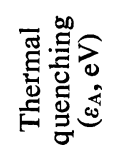 & Remarks & $\begin{array}{c}\text { Conclusion as to } \\
\text { nature of } 1.4 \mathrm{eV} \text { band }\end{array}$ \\
\hline $\begin{array}{l}{[1]} \\
\text { De Nobel } \\
\text { (1959) }\end{array}$ & CdTe : In & $\begin{array}{l}1.41- \\
1.43\end{array}$ & & & & & \begin{tabular}{|} 
Peak shift of $\sim 0.02 \mathrm{eV}$ noted \\
depending on Cd-vapor firing \\
conditions. $V_{\text {Cd has acceptor }}$ \\
level at $\varepsilon_{\mathrm{v}}+0.15 \mathrm{eV}$
\end{tabular} & $\begin{array}{l}\text { Data presented appear consis- } \\
\text { tent with CB-A or D-A tran- } \\
\text { sitions terminating on } V_{\mathrm{c}} \\
\text { acceptor level. }\end{array}$ \\
\hline $\begin{array}{c}\text { [22] } \\
\text { Barnes and } \\
\text { Zanio } \\
(1975)\end{array}$ & CdTe : In & & $\overline{1.454}$ & & & & $\begin{array}{l}\text { Closely-compensated samples. } \\
\text { lum intensities scale well } \\
\text { with defect chemistry calc. of } \\
V_{\text {cd-In complex concentra- }} \\
\text { tion. }\end{array}$ & $\begin{array}{l}\text { Transitions to acceptor levels } \\
\text { produced by NN } V_{\mathrm{Cd}-\mathrm{In}} \\
\text { complexes. }\end{array}$ \\
\hline $\begin{array}{l}\text { Present } \\
\text { Work }\end{array}$ & $\begin{array}{l}\text { CdTe : In } \\
\text { CdTe : Cl }\end{array}$ & $\begin{array}{l}1.42 \\
1.45 \\
1.45\end{array}$ & $\begin{array}{l}1.455 \\
1.475\end{array}$ & $\begin{array}{l}\times \\
\times\end{array}$ & $\begin{array}{l}\times \\
\times\end{array}$ & $\begin{array}{l}0.09- \\
0.103 \\
0.137\end{array}$ & $\begin{array}{l}\text { Closely compensated samples. } \\
\text { No band shift with il or } T \text {. } \\
\text { Half-width increases with } T \text {. } \\
\text { Frequency response is inde- } \\
\text { pendent of doping level. Band } \\
\text { shape unaffected by severe } \\
\text { quenching from implant da- } \\
\text { mage introduction. } \Delta \varepsilon \text { bet- } \\
\text { ween In and } C l \text { doping sug- } \\
\text { gests NN } V_{\mathrm{Cd}-\mathrm{D} \text { complexes }} \\
\text { in both cases. }\end{array}$ & $\begin{array}{l}\text { CB-A or intracenter transi } \\
\text { tions involving compact, pro- } \\
\text { bably NN } V_{\mathrm{Cd}}-\mathrm{D} \text { complexes } \\
\text { Acceptor levels, at approx } \\
\varepsilon_{\mathrm{v}}+0.1 \text { eV, normally cou } \\
\text { pled to VB. Donor levels, I } \\
\text { present, weakly coupled to } \\
\text { CB. }\end{array}$ \\
\hline
\end{tabular}

origins in Cd-rich and Te-rich CdTe, and in some cases the stoichiometry of the material investigated has not been known. Another problem is that comprehensive luminescence studies, that is, studies involving a variety of methods such as injection level dependence, dynamic behavior, and thermal quenching, are lacking except for the work of Taguchi, et al. [8-13] on Cdrich CdTe. Even in the latter case, where the injection level behavior and time dependence of the $1.4 \mathrm{eV}$ luminescence are consistent with distributed donoracceptor pair transitions, the conclusion that D-A transitions are responsible for the $1.4 \mathrm{eV}$ band is not convincing because the measured thermal quenching behaviour [10] shows a large activation energy that is not consistent with D-A transitions involving shallow donors but can readily be explained in terms of conduction-band-to-acceptor transitions.

The thermal quenching results of Taguchi, et al. [10] are similar to those of Bryant and Totterdell [15] and Bryant and Webster [17] for Te-rich CdTe. In refs. [15] and [17] the quenching results were interpreted as definite evidence that the $1.4 \mathrm{eV}$ band resulted from conduction-band-to-acceptor transitions. In addition, it has been suggested by Agrinskaya, et al. [7] that the $1.4 \mathrm{eV}$ band results from intracenter transitions that occur within compact defect-dopant complexes, similar to the complexes shown to exist in defect chemistry calculations used to explain self-compensation in intentionally donor-compensated CdTe. However, the experimental evidence behind this conclusion is rather limited.

In reviewing the literature [1-24] we are unable to find any single case where, in our estimation, the ori- gin of a $1.4 \mathrm{eV}$ band in $\mathrm{CdTe}$ has been convincingly explained. In this paper we describe comprehensive cathodoluminescence measurements intended to clarify this puzzling situation. We will show that, in the samples studied, the $1.4 \mathrm{eV}$ band results from a more complex type of transition than has generally been appreciated by previous investigators, and that in no case does the transition appear to be of a simple conduction-band-to-acceptor or donor-acceptor pair nature.

2. Experiment. - We have studied both nominally stoichiometric, nominally undoped $\mathrm{CdTe}$ obtained from the late R. E. Halsted at General Electric Co. and Te-rich, donor-compensated $\mathrm{CdTe}$, with either In or $\mathrm{Cl}$ doping and widely-varying dopant concentrations, obtained from K. R. Zanio at Hughes Research Labs. The known characteristics of the samples studied are given in table II. On each of the samples we measured injection level dependence and frequency response using cathodoluminescence at $80 \mathrm{~K}$. We also measured thermal quenching of the cathodoluminescence from $80 \mathrm{~K}$ to $200 \mathrm{~K}$. In addition, on some samples we used photoluminescence to measure injection level dependence at $4 \mathrm{~K}$ and to measure thermal quenching from $4 \mathrm{~K}$ to $100 \mathrm{~K}$. The spectra to be presented have been corrected for the wavelength response of the optical detection system using computer processing.

The injection level behaviour of the $1.4 \mathrm{eV}$ band has been measured in two ways. The first way is simply the classical method of increasing the injection level and noting the shift, if any, in the peak location 
TABLE II

CdTe sample parameters

\begin{tabular}{|c|c|c|c|}
\hline Sample & Material & Doping level & Other data \\
\hline CTG-50 & $\mathrm{CdTe}$ & Nom. undoped & Resistivity $\sim 1 \mathrm{ohm}$-cm; n-type, high mobility \\
\hline CTH-111 & $\mathrm{CdTe}: \mathrm{Cl}$ & $1.5 \mathrm{E} 16 / \mathrm{cm}^{3}$ & Resistivity $\sim 1 \mathrm{E} 4$ ohm-cm, p-type \\
\hline CTH-12B1 & $\mathrm{CdTe}: \mathrm{Cl}$ & $1.5 \mathrm{E} 17 / \mathrm{cm}^{3}$ & Resistivity $\sim 1 \mathrm{E} 8 \mathrm{ohm}-\mathrm{cm}$ \\
\hline CTH-12B2 & $\mathrm{CdTe}: \mathrm{Cl}$ & $1.5 \mathrm{E} 17 / \mathrm{cm}^{3}$ & Same wafer as CTH-12B1 \\
\hline CTH-20A & $\mathrm{CdTe}:$ In & $3 \mathrm{E} 15 / \mathrm{cm}^{3}$ & Resistivity $\sim 1 \mathrm{E} 8 \mathrm{ohm}-\mathrm{cm}$ \\
\hline CTH-26 & $\mathrm{Cd} \overline{\mathrm{Te}}:$ In & $3 \mathrm{E} 16 / \mathrm{cm}^{3}$ & $\begin{array}{l}\text { Resistivity } \sim 1 \mathrm{E} 8 \mathrm{ohm}-\mathrm{cm} ; \\
\mu \tau \text { product } \sim 1 \mathrm{E} 3 \mathrm{~cm}^{2} / \mathrm{V}\end{array}$ \\
\hline CTH-22 & CdTe : In & Unknown & $\begin{array}{l}\text { Resistivity } \sim 1 \mathrm{E} 8 \mathrm{ohm}-\mathrm{cm} ; \\
\mu \tau \text { product } \sim 1-2 \mathrm{E}-5 \mathrm{~cm}^{2} / \mathrm{V}\end{array}$ \\
\hline CTH-24D & CdTe : In & $1 \mathrm{E} 18 / \mathrm{cm}^{3}$ & Resistivity $=1 \mathrm{E} 2-1 \mathrm{E} 3 \mathrm{ohm}-\mathrm{cm}, \mathrm{n}$-type \\
\hline
\end{tabular}

and band shape as a function of injection level. The second method, which gives more graphic results, involves exciting cathodoluminescence with a sinusoidal, harmonic-free electron beam and then recording both the fundamental and harmonic-frequency spectra. If a second-harmonic signal is detected, then the luminescence band has a non linear injection level dependence. If the sign of the second harmonic signal is negative, the injection level dependence is sublinear. If the sign of the second harmonic signal is positive, the injection level dependence is superlinear. If it happens that the shape of the second harmonic spectrum matches that of the fundamental frequency luminescence spectrum after appropriate amplitude normalization, then the band center and shape are independent of injection level.

The dynamic behavior of the $1.4 \mathrm{eV}$ transitions in CdTe was measured using the frequency response of the luminescence under excitation by a sinusoidallymodulated electron beam under conditions of constant beam energy, injection level, and sample temperature. The frequencies of beam modulation and photomultiplier signal detection were varied in decade increments from $50 \mathrm{~Hz}$ to $50 \mathrm{MHz}$. At $50 \mathrm{kHz}$ and below, the carrier was unmodulated and phasesensitive detection was employed at carrier frequency. From $500 \mathrm{kHz}$ to $50 \mathrm{MHz}$, the carrier signal was modulated at $400 \mathrm{~Hz}$. At these frequencies the signal detection was asynchronous but the $400 \mathrm{~Hz}$ modulation was synchronously detected to enhance the signal-tonoise ratio.

3. Results and discussion. - Combined fundamental and harmonic spectra were taken on all the samples studied, with results typically similar to those shown in figure 1. Since the fundamental and second harmonic spectra virtually coincide for the $1.4 \mathrm{eV}$ band in figure 1 , we conclude that both the shape and peak location of the $1.4 \mathrm{eV}$ band are independent of injection level. This behavior, which is confirmed by parallel injection level studies using $4 \mathrm{~K}$ photolumi- nescence where the no-phonon peak is clearly resolved, is inconsistent with distributed donor-acceptor pair transitions. Although the spectra in figure 1 should

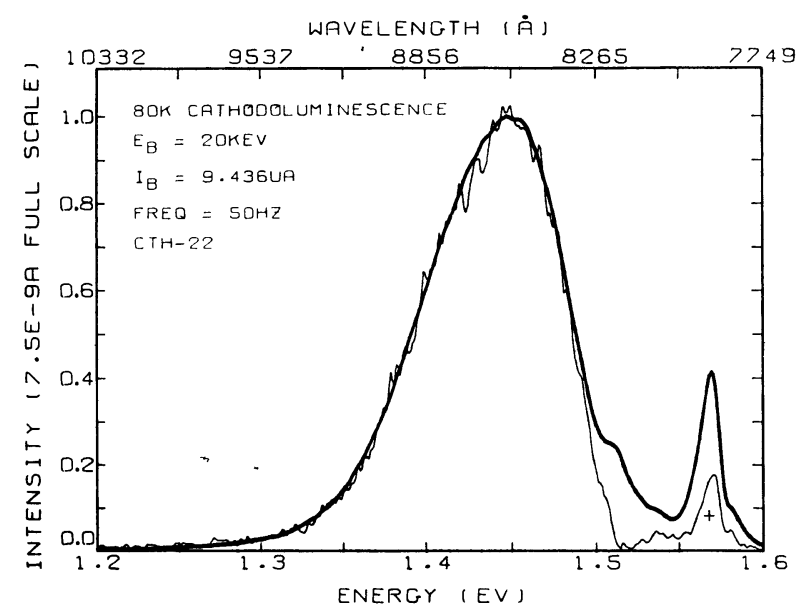

FIG. 1. - Typical fundamental (heavy line) and second harmonic (light line) spectra for donor-compensated CdTe. The phases of the second harmonic signal indicate that the $1.4 \mathrm{eV}$ band is sublinear, while the near-bandedge luminescence at $1.57 \mathrm{eV}$ is superlinear. This sample does not show an injection level shift of the $1.4 \mathrm{eV}$ band.

be regarded as typical, it is important to note that it is not difficult to find anomalous samples in which there are overlapping bands or other effects that lead to an apparent injection level shift. An example of this behaviour is shown in figure 2 .

In figure 2 the shape and peak energy of the $1.4 \mathrm{eV}$ band shift with injection level because the fundamental and harmonic spectra do not coincide in this case. Since the high-energy side of the unresolved band is less sublinear than the low energy side, the $1.4 \mathrm{eV}$ band in this sample will shift to higher energy as the injection level is increased. The presence of overlapping bands in the sample characterized in figure 2 is confirmed by frequency-resolved cathodoluminescence, in which the component bands show somewhat different frequency response; by thermal quenching measure- 


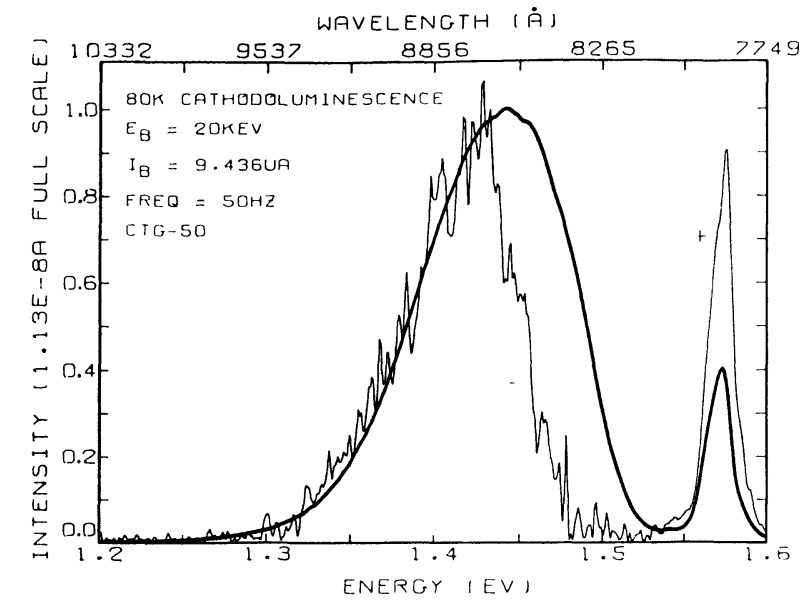

Fig. 2. - Fundamental and second harmonic spectra for a nominally undoped CdTe sample. In this case there is an apparent injection level shift of the $1.4 \mathrm{eV}$ luminescence arising from overlapping bands.

ments, in which the component bands show slightly different quenching behavior ; and by $4 \mathrm{~K}$ photoluminescence measurements, in which the component no-phonon peaks and their phonon replicas can be resolved. Other effects which can lead to an injection level shift are impurity banding and band waviness, which occur at high concentrations of impurities and/or defects. The $1.4 \mathrm{eV}$ band in the most heavily Indoped sample (CTH-24 D) shows a large injection level dependence which we ascribe to one or both of these effects. In fact, it appears that the $\varepsilon_{\mathrm{v}}+\sim 0.1 \mathrm{eV}$ impurity band has tailed into the valence band in this sample since the edge emission is orders of magnitude weaker than in other samples. Of the total of eight samples studied, three samples showed injection level shifts. Although it is clear that the basic $1.4 \mathrm{eV}$ transition is characterized by a lack of injection level shift, the frequent occurrence of anomalous samples which exhibit injection level shifts is one possible explanation for the contradictory injection level results that have been reported in the literature for the $1.4 \mathrm{eV}$ bands.

Next, we discuss the results of the frequencyresolved cathodoluminescence measurements. These measurements give information on the transition dynamics analogous to that obtained from the more familiar time-resolved luminescence methods. However, the frequency-resolved measurements can be carried out at a constant average injection level, and significantly greater sensitivity is often possible. Figure 3 shows a sequence of cathodoluminescence spectra taken under identical conditions of sample temperature, injection level, and electron beam energy, but using frequencies of electron beam modulation and photomultiplier signal detection ranging from $50 \mathrm{~Hz}$ to $50 \mathrm{MHz}$. Qualitatively speaking, slow transitions will not be visible in the high-frequency spectra because the response of the transition is not

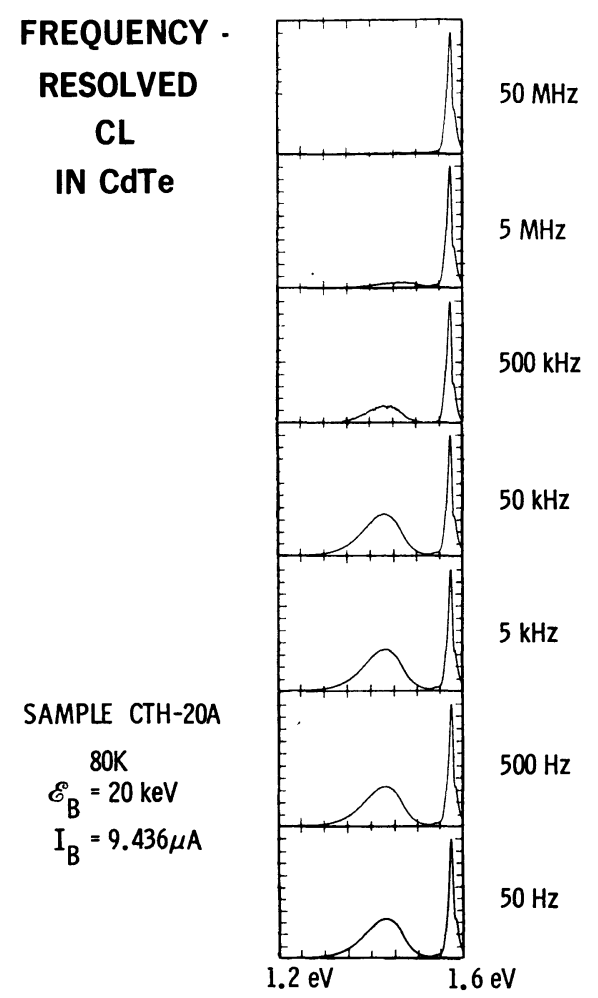

Fig. 3. - Sequence of cathodoluminescence spectra for CdTe taken at frequencies of beam modulation and photomultiplier signal detection ranging from $50 \mathrm{~Hz}$ to $50 \mathrm{MHz}$. These spectra are normalized using the band-edge peak as reference. It is apparent that the transition responsible for the $1.4 \mathrm{eV}$ luminescence is considerably slower than that responsible for the band-edge luminescence.

able to follow the rapidly-varying modulation. Thus, in following the sequence of spectra in figure 3 from low to high frequencies, it is apparent that the response of the $1.4 \mathrm{eV}$ band is considerably slower than that of the band-edge luminescence.

Figures 4-6 show the frequency dependence of luminescence quantitatively, in the form of plots of $\log$ luminescence intensity vs. $\log$ modulation fre-

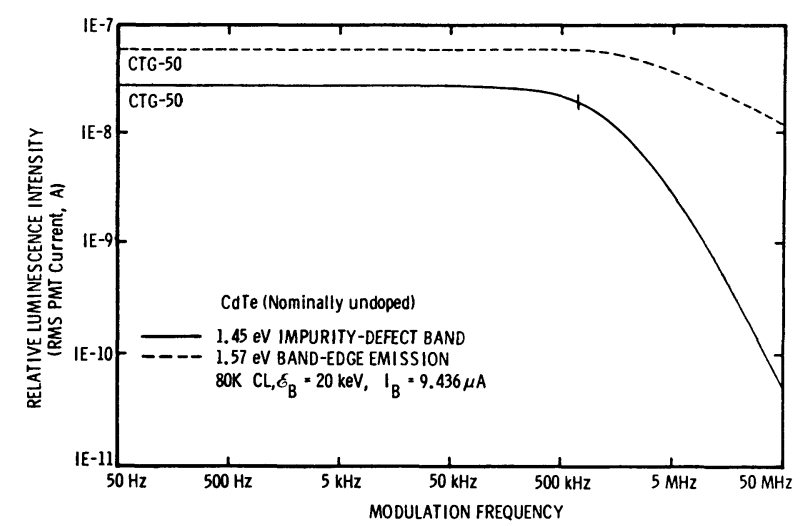

FIG. 4. - Frequency response plot for bands in nominally undoped CdTe. The response of the $1.4 \mathrm{eV}$ band indicates a non-exponential time decay with a characteristic time of the order of $1 \mathrm{E}-6 \mathrm{~s}$. 
quency at constant injection level, for all the samples investigated. Figure 4 shows frequency response for the bands in nominally stoichiometric, nominally undoped CdTe. The solid lines show the frequency response of the $1.4 \mathrm{eV}$ band, and the dashed lines show the frequency response of the $1.57 \mathrm{eV}$ band-edge emission. Since figure 4 is a log-log presentation, it is clear that the response of the $1.4 \mathrm{eV}$ band falls off dramatically at high frequencies, as shown qualitatively in figure 3 .

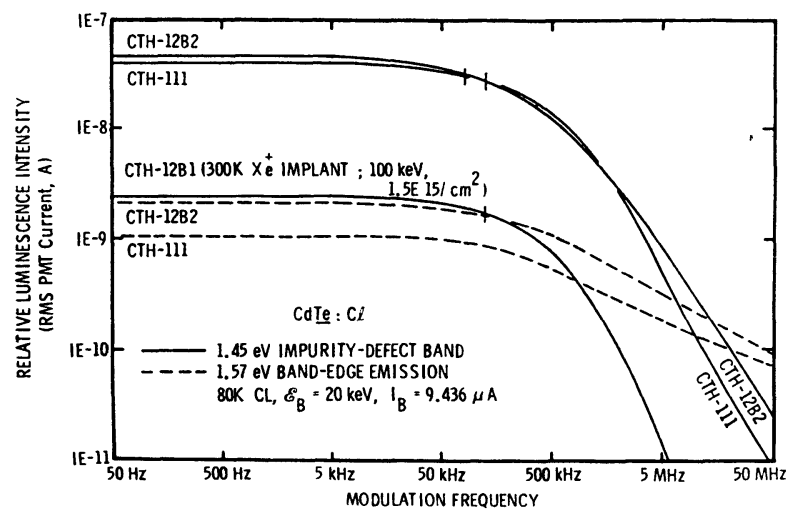

FIG. 5. - Frequency response plot for bands in Cl-doped CdTe. The response of the $1.4 \mathrm{eV}$ bands indicates a non-exponential time decay with a characteristic time of the order of $5 \mathrm{E}-6 \mathrm{~s}$.

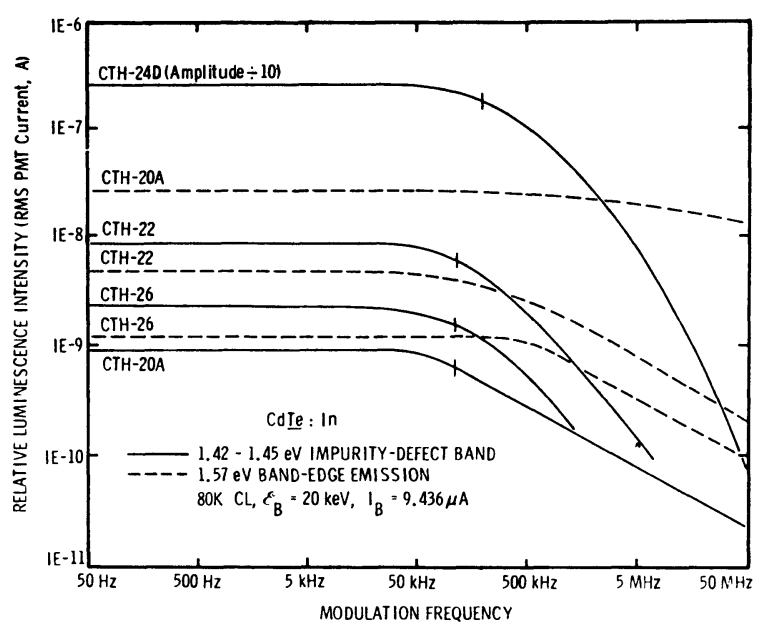

FIG. 6. - Frequency response plot for bands in In-doped CdTe. The response of the $1.4 \mathrm{eV}$ band indicates a non-exponential time decay with a characteristic time on the order of $5 \mathrm{E}-6 \mathrm{~s}$.

Figure 5 shows frequency response data for three samples of $\mathrm{Cl}$-doped $\mathrm{CdTe}$. The frequency response of the bands in the Cl-doped CdTe is qualitatively similar to that in the nominally-undoped material. However, by comparing figures 4 and 5 it may be seen that the $1.4 \mathrm{eV}$ transitions in the donor-compensated material are somewhat slower than in the nominally undoped material. In addition, figure 5 shows that the transition response in the $\mathrm{Cl}$-doped CdTe is unaffected by a tenfold change in doping level. The transition response is also unaffected by introduction of ion implantation damage that results in a tenfold quenching of the $1.4 \mathrm{eV}$ luminescence.

Figure 6, which shows corresponding frequency response data for four samples of In-doped CdTe, also reveals a similar pattern of results. Now, however, we are able to verify that the frequency response of the $1.4 \mathrm{eV}$ transition is practically unaffected by indium concentration over a thousand-fold range. This result argues against any distributed donoracceptor pair interpretation of the $1.4 \mathrm{eV}$ luminescence because the mean pair separation, and thus the transition response, would be expected to vary significantly over such a wide range of dopant concentrations if the transitions involved isolated donors. However, it is clear that the donor species must somehow be associated with the luminescence transition, because of the fact that the relative strength of the $1.4 \mathrm{eV}$ luminescence increases with donor concentration, as can be seen in figures 5 and 6 . Thus the relative invariance of the transition response in the donor-compensated $\mathrm{CdTe}$ argues in favor of the luminescence transition being associated with a compact center involving donors.

In addition, we find that there is a shift of approximately $+20 \mathrm{meV}$ in the no-phonon peak of the $4 \mathrm{~K}$ photoluminescence spectrum between In-doped and Cl-doped CdTe (see table I). The corresponding shift expected on the assumption that the center is a nearest-neighbor $\mathrm{V}_{C \mathrm{Cd}}$-donor complex has been estimated to be $+30 \mathrm{meV}$ by Agrinskaya et al. [7]. The shift we observe argues that the $1.4 \mathrm{eV}$ luminescence transition in donor-compensated CdTe involves donordefect associates that are at least compact, and probably of nearest-neighbor configuration.

The thermal quenching behaviour of the Cl-doped, In-doped, and nominally-undoped CdTe samples is shown in figure 7 for temperatures of $80 \mathrm{~K}-200 \mathrm{~K}$. The undoped and In-doped samples show quenching activation energies of $0.09-0.103 \mathrm{eV}$. The $\mathrm{Cl}$-doped samples show a somewhat higher activation energy of $0.137 \mathrm{eV}$. As is customarily done, we assume that quenching of the luminescence occurs because of thermal population of the participating acceptor level. In terms of relating the thermal quenching results to energy levels and the band edges, it is well known that thermal and optical activation energies are expected to differ somewhat, with the optical activation energy generally being greater than the thermal activation energy. The expected difference between these energies in CdTe has been calculated and found to be less than one percent [17]. If we assume that the thermal activation energy of the acceptor level is approximately the same as the energy of a hypothetical radiative transition from acceptor 
level to valence band, then we can estimate the energy of the donor levels, if any, involved in the $1.4 \mathrm{eV}$ luminescence. For this estimate we use the quenching activation energies determined from $30 \mathrm{~K}-80 \mathrm{~K}$ photoluminescence measurements (the data are similar to those of figure 7), together with the energies of the

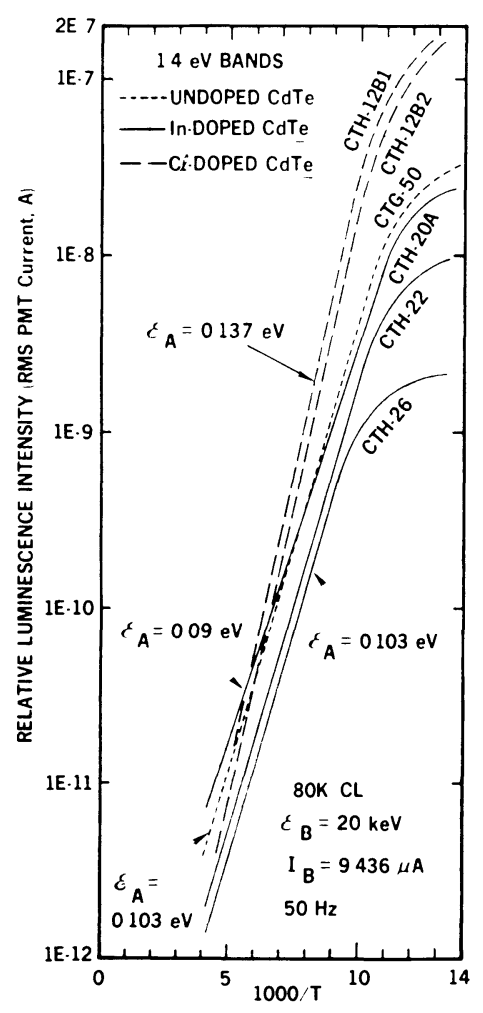

FIG. 7. - Thermal quenching behavior of all types of CdTe samples studied.

no-phonon peaks in the $4 \mathrm{~K}$ photoluminescence spectrum, which occur at approximately $1.455 \mathrm{eV}$ for In-doped CdTe and $1.475 \mathrm{eV}$ for $\mathrm{Cl}$-doped CdTe. We find that in all cases the donor levels, if present, must lie within hundredths of an $\mathrm{eV}$ above or below the conduction band, whereas the acceptor levels are approximately a tenth of an $\mathrm{eV}$ from the valence band. Therefore the assumption of donor levels leads to a paradox because of the fact that the deeper accep- tor levels are dominating the thermal quenching. Thus, if any donor levels are involved in the $1.4 \mathrm{eV}$ transition, the quenching results indicate that these levels are not in normal thermal equilibrium with the conduction band. It should be mentioned that there is precedence for the existence of thermally disconnected levels near the conduction band in results from photoconductivity and thermally stimulated current measurements on CdTe $[25,26]$. However, there is no direct evidence that such levels are participating in the $1.4 \mathrm{eV}$ transition.

3. Conclusion. - It is not clear that donor levels of any kind are necessarily involved in the $1.4 \mathrm{eV}$ luminescence. The proximity of the initial state to the conduction band may also be taken to suggest that there is, in fact, no discrete donor level involved and that instead the conduction band continuum is the initial state. In this case, the injection level dependence and thermal quenching behavior would be consistent with our experimental results, and the relatively slow transition response must be explained. Possibly this transition is slow because it is partially forbidden. The absence of a donor level in the known presence of donors could be accounted for by the close association of singly ionized donors and double acceptors, such as cadmium vacancies.

There is also the possibility that the $1.4 \mathrm{eV}$ luminescence in CdTe is the result of an intracenter transition in compact donor-cadmium vacancy complexes [7] similar to those known by EPR measurements to be involved in the self-activated luminescence in $\mathrm{ZnS}$ [27]. At the present time, it appears that this proposal and the forbidden conduction-band-toacceptor hypoth esis are the most promising candidates for explaining the unusual characteristics of the $1.4 \mathrm{eV}$ luminescence in CdTe. Additional experiments will be necessary to decide between the two hypotheses. At any rate, it is now clear that at least some of the confusion regarding the $1.4 \mathrm{eV}$ luminescence in $\mathrm{CdTe}$ has arisen because the transition is of a more complex nature than generally anticipated.

Acknowledgement. - The authors wish to thank D. T. Stuart and L. V. Hansen for assistance with the measurements reported in this paper.

\section{References}

[1] DE Nobel, D., Philips Res. Repts. 14 (1959) 361 and 430.

[2] Garlick, G. F. J., J. Phys. \& Chem. Solids 8 (1959) 449.

[3] Halsted, R. E., Lorenz, M. R. and Segall, B., J. Phys. \& Chem. Solids 22 (1961) 109.

[4] Vavilov, V. S., Gippius, A. A. and Panossian, J. R. in II-VI Semiconducting Compounds, edited by D. G. Thomas (W. A. Benjamin, Inc., New York, 1967), pp. 743754.

[5] Agrinskaya, N. V., Arkad'eva, E. N., Guseva, M. I., Maslova, L. V., Matveev, O. A., Ryvkin, S. M., Sladkova, V. A. and Starinin, K. V., in Proc. International Symp. on Cadmium Telluride, edited by P. Siffert and A. Cornet (1971), paper XVI-1.
[6] Agrinskaya, N. V., Arkad'eva, E. N. and Matveev, O. A., Sov. Phys. Semicond. 4 (1970) 347.

[7] Agrinskaya, N. V., Arkad'eva, E. N. and Matveev, O. A., Sov. Phys. Semicond. 55 (1971) 767.

[8] TAGUChI, T., ShirafujI, J. and INUISHI, Y., in Radiation Damage and Defects in Semiconductors (The Institute of Physics, London, 1972), pp. 407-415.

[9] TAGUChI, T., ShirafujI, J. and INUISHI, Y., in Luminescence of Crystals, Molecules, and Solutions, edited by F. Williams (Plenum Press, New York, 1973), pp. 258-261.

[10] TAguchi, T., Shirafuil, J. and INUISHI, Y., Japan. J. Appl. Phys. 12 (1973) 1558. 
[11] TAguchi, T., Shirafuj,, J. and INUishi, Y., Japan. J. Appl. Phys. 13 (1974) 1003.

[12] TAGUChI, T., Shirafuit, J. and InUishi, Y., Japan. J. Appl. Phys. 13 (1974) 1169.

[13] Taguchi, T., Shirafuji, J. and InUishi, Y., Inst. Phys. Conf. Ser. No. 23 (1975) 272.

[14] Rud', Y. V., Sanin, K. V. and Shreter, Y. G., Sov. Phys. Semicond. 5 (1971) 573.

[15] Bryant, F. J. and Totterdell, D. H. J., Phys. Stat. Sol. (a) 10 (1972) K 75.

[16] Bryant, F. J. and Webster, E., Brit. J. Appl. Phys. (J. Phys. D), 1 (1968) 965.

[17] Bryant, F. J., Totterdell, D. H. J. and Hagston, W. E., Phys. Stat. Sol. (a) 14 (1972) 579.

[18] Panossian, J. R., Gippius, A. A. and Vavilov, V. S., Phys. Stat. Sol. $35(1969) 1069$.

[19] Furgolle, B., Hoclet, M. and Vandevyver, M., Solid State Commun. 14 (1974) 1237.
[20] Marfaing, Y., Triboulet, R., Furgolle, B., Hoclet, M. and Vandevyver, M., Inst. Phys. Conf. Ser. No. 23 (1975) 288.

[21] Barnes, C. E. and Zanio, K., J. Appl. Phys. 46 (1975) 3959.

[22] Barnes, C. E. and KiKUCHI, C., Radiat. Effects 26 (1975) 105.

[23] Noblanc, J. P. and Duraffourg, G., Phys. Stat. Sol. (b) 46 (1971) 705.

[24] Bryant, F. J., Cox, A. F. J. and Webster, E., J. Phys. $C$ (Proc. Phys. Soc.) 1 (1968) 1737.

[25] Barnes, C. E. and Zanio, K., IEEE Trans. Nucl. Sci. NS-23 (1976) 177

[26] UrLI, N. B., in II-VI Semiconducting Compounds, edited by D. G. Thomas (W. A. Benjamin, Inc., New York, 1967), pp. 1335-1347.

[27] See, for example, Curie, D. and Prener, J. S., in Physics and Chemistry of II-VI Compounds, edited by M. Aven and J. S. Prener (American Elsevier, 1967), pp. 445 ff. 